\title{
The Construction of the Teacher's Authority in Pedagogic Discourse
}

\author{
Xing Wenren ${ }^{1}$ \\ ${ }^{1}$ School of International Studies, Zhejiang University, China \\ Correspondence: Xing Wenren, School of International Studies, Zhejiang University, No. 866 Yuhangtang Road, \\ 310058 Hangzhou, Zhejiang, China. Tel: 86-571-8808-9475. E-mail: wenren_zju@163.com
}

Received: March 8, 2014 Accepted: April 9, 2014 Online Published: May 14, 2014

doi:10.5539/elt.v7n6p96 URL: http://dx.doi.org/10.5539/elt.v7n6p96

\begin{abstract}
This article examines the discursive construction of the authoritative identity of teachers in relation to a number of issues in the classroom context, including identity negotiation, pedagogic discourse and teacher-student power relationship. A variety of classroom teacher talks are analyzed from a discourse analytical perspective, revealing the core constituent parts of the teacher's authoritative identity and the constructive process of the authoritative discourse. The analysis shows that different combinations of the constituent parts make up distinctive frameworks of the teacher's authoritative status. The discursive choices that emerge in the negotiation of the authoritative identity result in a strong or a weak form of authority. The article concludes with a discussion of the relevance of the teacher's authoritative identity to pedagogic discourse and teacher-student power relations.
\end{abstract}

Keywords: teacher's authoritative identity, discourse analysis, pedagogic discourse, teacher-student power relation

\section{Introduction: Authority and Identity}

The identity of a teacher as an authority begins the moment he or she enters the classroom. The teacher summons the students' attention, organizes learning-related activities, presents new knowledge, disciplines undesired behavior of students, gives feedback, and announces the end of class. This authority is present more or less explicitly throughout any lesson in any classroom, even though the instructional content and activities may vary. Authority is one of the core constituents of the professional identity of the teacher and an essential guarantee of effective classroom management and instruction.

\subsection{Literature Review}

Commenting on the structuring of pedagogic discourse, Bernstein (1990, p. 159) states that "[i]t is of course obvious that all pedagogic discourse creates a moral regulation of the social relations of transmission/acquisition, that is, rules of order, relation, and identity, and that such a moral order is prior to, and a condition for, the transmission of competences." In the classroom, the rules of order, relations and identities must be established prior to the transmission of subject knowledge.

Numerous studies have been done on teachers' identity (Preuss \& Hofsass, 1991; Siraj-Blatchford, 1993; Beijaard, 1995; Antonek, McCormick, \& Donato, 1997; Mawhinney \& Xu, 1997; Coldron \& Smith, 1999; Connelly \& Clandinin, 1999; Samuel \& Stephens, 2000; Beijaard, Verloop, \& Meijer, 2000; Beijaard, Meijer, \& Verloop, 2004). At the conceptual level, these studies stress the developmental process of identity formation, in which the teacher's professional identity is seen as mobile and negotiable, closely connected to self-reflection and self-development, and determined by contextual factors such as educational policies, social networks and teaching contexts. In a comprehensive study of Beauchamp \& Thomas (2009), we also see "the constant reinventing of themselves that teachers undergo". Many of the data are narrative in which teachers tell about their subjective understanding as professionals, about the developmental nature of identity formation and about their teaching lives. These data focus on unique discursive subjects and differences in the process of self-realization, indicating that identity is inconsistent and sometimes paradoxical. Just as in sociology and psychology where the concern with the personal identity and the current "liquid modernity" may "corrode the resources people can draw upon to configure a sense of self" (Wetherell, 2010, pp. 3-4), contemporary research on teachers' identity is likewise characterized by the subjective, idiosyncratic formation of identity, the confusion and conflict within the teacher. 
However, this has disregarded the social, collective and continuous nature of the professional identity of teachers. While we admit that "sociocultural identities are not static, deterministic constructs that teachers bring to the classroom and take away unchanged at the end of a lesson, nor are they simply dictated by membership in a larger social, cultural, or linguistic group" (Duff et al., 1997), there might be little objection that professional identity is a social concept rather than an undetermined and ever-changing one. Identity, as defined by Gee, is "always and everywhere social and products of social histories." (2005, p. 10) According to Tajfel (1974), social identity is "that part of an individual's self-concept which derives from his knowledge of his membership of a social group (or groups) together with the emotional significance attached to that membership." Professional identity is a set of roles which represent the core values of members within the profession. They are socially acknowledged, traditionally honored and institutionally guaranteed qualifications, rather than mostly idiosyncratic and shifting features. In this sense, the professional identity of the teacher is stable over time and easily recognized. With this stable and distinctive repertoire of features of identification, teachers know who they are, what meanings are attributed to their identity, as well as the power and authority they are entitled to.

The interest in how teachers' power is acted out in micro interaction has led researchers to look at the structure of instructional events (Barnes, Britton, \& Torbe, 1969; Sinclaire \& Coulthard, 1992; Seliger \& Long, 1983; Cazden, 2001; Christie, 2002; Rymes, 2009). They find that teachers generally exercise their authority by controlling topics and taking up more turns of talk.

However, within this substantial body of literature, authority, an essential part of teacher's identity, tends to be discussed mainly at the conceptual level. It has received scant attention as a discursive object for analysis, and is formulated rather abstractly. There has been so far little discussion of the actual discourse of teachers in the construction of their authority, the relationship between the micro level of language and teachers' macro identity, and between their authoritative identity and their pedagogic discourse.

Obviously, teacher's authority is in large part constructed by discourse. It would be wrong to suppose that authority is just there, and there is no need or no space for negotiation or flexibility. Therefore, this paper proposes that a discourse analytical perspective would be vitally important because without looking at the actual spoken discourse in the classroom, it would be impossible to understand the linguistic resources that teachers employ to actualize or negotiate their status of authority. On the other hand, it would be difficult for teachers to reflect on their own discourse and find how they themselves are using the discourse to establish their status. A discourse analysis of authority brings out the linguistic representations of teachers' epistemology of identity and knowledge. It relates teachers' power discourse to their ideology, so that the relationship between the macro-factors of power and micro factors is revealed. This paper further proposes a framework of the combination of the micro and macro factors, hoping to provide theoretical and practical guidance for studying teachers' discourse of authority.

Before we go into discourse analysis, it is necessary to examine the concept of discourse which is closely related to authority.

\subsection{Discourse and Authority}

Language plays an important role in authority construction. Sociolinguists believe that social identity is "in large part established and maintained through language" (Gumperz, 1982, p. 7). Van Dijk writes: "Without communication - text and talk-power in society can hardly be exercised and legitimated" $(2008$, p. 64). Gee claims that to study matters of power and equity, we must study language because "it is in and through different social languages...that we enact, perform and recognize different socially-situated identities" (2001, p. 130).

The research in discourse analysis and critical discourse analysis has identified various linguistic resources and discursive strategies to construct power relations. People may build power relations by establishing social categories, e.g. by polarization of "us" and "them" (van Dijk, 1995), or self and "otherness" (Weiss \& Wodak, 2003), or by labeling and nominalization (van Leeuwen, 1996; Hodge \& Kress, 1993). Others have identified the colonization of institutional orders of discourse (Fairclough, 1989) by legalization and naturalization (Rojo \& van Dijk, 1997) and the imposition of images and identities by internalization (Grad \& Rojo, 2008), etc.

As a kind of symbolic power, teachers' knowledge and institutional status shift from the symbolic level to the social level of power and dominance mainly through the medium of discourse (Manke, 1997; de Fina, 2006; Kamila, 2011). An analysis of the teacher's discourse may reveal the details of the daily constitutive practices of power and authority. 


\section{The Professional Identity and Authority of Being a Teacher}

The instructional character of educational institutions privileges qualities which are knowledge-related and instructionally goal-oriented. The more professional qualities an individual possesses, the more authority this individual usually has in the teaching context.

In the following sections, we discuss the major discursive resources from which teachers' authoritative identity is constructed. We illustrate the construction of authority with detailed analyses of classroom discourse. We then discuss how these resources affect teachers' perceptions of their authority and the implications of these perceptions for their pedagogic discourse. We find that with the active agency of the teachers, there emerge a strong form and a weak form of authoritative identity. That is, different linguistic choices may result in different combinations of teachers' authority, and consequently teachers may present themselves as more institutionally empowered or academically open-minded, more dominant or more power-conceding toward students.

\subsection{Constituents of Teachers' Authoritative Identity}

McInnis cited Sullivan's (2000) three perspectives of professionalization: the control over the market for services gained by superior knowledge combined with claims of special moral integrity, the cultural and social authority to define and control a specific area of expertise, and the perspective of professionalization as an ideology of social reform, with social responsibility as the primary characteristic (2010, pp. 148-149). In our discussion, we identify four major sources of teachers' authority: 1) expertise in subject matter, 2) power in managing teaching-related activities, 3) traditions and moral values and 4) social influence.

Expertise in Subject Matter. Although knowledge is a symbolic resource (Van Dijk, 1996), it is the most important constituent of the teacher's institutional authority. Most institutions require teaching certificates or educational degrees as proof of one's level of expert knowledge. They are an indication of special knowledge based on long training. The constituent of expertise carries more weight than other peripheral identity constituents like accessibility as advisor or patience. Without expertise in subject matter, one would lose the core qualification of being a professional teacher. Since students are in school primarily to obtain knowledge and since the chief evaluation of a student's academic performance is the width and depth of knowledge (for example, one of the sentences in college graduation certificates may be "graduated with academic excellence", or "met the academic requirements of all subjects"), the most desired thing in the school is knowledge. According to Jaffe, knowledge is a social resource which "legitimates further acts of evaluation" (2009, p. 7). To be a member of the instructional group who not only possess this most desired resource, but also are able to judge the value and correctness of this resource carries the greatest power and authority in the classroom. As a matter of fact, teachers generally feel that their authority is threatened and their professionalism undermined when they have to teach outside their subject (McInnis, 2010).

Management of Teaching-Related Activities. Although the curriculum and general course objective may not be decided by the individual teacher, he or she is responsible for the pacing of teaching, the management of course assignments, classroom discipline, the evaluation of academic performance in accordance with the general goals and standards of a course and other teaching-related issues. The management responsibilities and rights are part of the institutional power which comes with the profession. This is a powerful support to the "subject matter expert" identity and guarantees that knowledge gets imparted to the targets and finally gets evaluated. This authoritative identity consists not only of what teachers can do at the moment, or did in the past, but also what they are able to do in the future. Attached to this power are a set of expectations about what behaviors are appropriate for the learning goals. For example, the authority to grant a reward or punishment is a delayed but definite part of the management power of the teacher.

Tradition and Moral Values. Teachers may present themselves as the symbols of tradition and high moral values of the society. Teachers are supposed to value service to students more highly than their personal profit. This is especially true of tradition-oriented societies. Such societies expect certain professions to be symbols of their values and to be modelled after by other people. Educational institutions are places where such values and traditions are passed down. Teachers often appear as defenders of such values and traditions, because their identity partially comes from them. The appeal to moral values alone would impose great pressure on others and therefore carries a lot of power.

Membership of Prestigious, Influential and Respectable Groups. The constituents of people's social identities in general also come into the framework of the institutional power of a teacher. A teacher's personal experience, for example, working and studying abroad, many years of teaching experience, even expertise in some other areas may constitute part of his or her authority as long as this is a desired resource that most people do not possess. Having as friends people who enjoy high social status implies that the teacher is a member of the 
elite group. The teacher's worldly knowledge may prove the soundness of his/her judgment. Taking positions in academic associations, authoring books, obtaining grants, speaking at important events, and academic entrepreneurship are all examples of a teacher's professional identity. They constitute a symbol of success that is achieved over time and that is not readily reproduced. Inclusion within such social groups heightens the individual's social status.

\section{The Framework of Choices}

Teachers attach different weights to the constituents of authority. They privilege those constituents which they perceive as being more important. Because these constituents convey different aspects of authoritative power, the combination of constituents brings out differently desired authoritative images of teachers. We find that with such combinations, there is always room for play in terms of the authoritative or de-authoritative stance that teachers take on.

Our framework identifies a high form and a low form of authority constituents. By "high form", we mean that the constituent is represented in the discourse in a way that is linguistically marked. To stress the high degree of certainty of their statements, teachers may make explicit and marked use of high value modality expressions (Halliday, 1985), high graduation (Martin et al., 2005) and plain assertions. They can set up categories, define boundaries and make judgments. By 'low form', we mean that the teacher uses fewer of these expressions, and takes a more neutral stance. For example, indirect commands would be comparatively unmarked when they are given with low value modality expressions (e.g. might, would, likely) instead of high modality (e.g. must, definitely, shouldn't). Expressions which establish the unquestionable state of knowledge, exclusion of other possible explanations and refusal to acknowledge different sources of information are categorized as marked. The more teachers exploit the kinds of discursive power in a marked way, the more likely they are in trying to indicate a strong form of authority.

\section{Data Description}

Our data consisted of approximately 28 hours of classroom videos in China. Some courses were videotaped with the teachers' permission; others were demonstration lectures posted on university websites. Some of them are entirely lecture-style; some are more interactive in nature. Whenever possible, interviews were conducted with the teachers, their administrators and their students.

All the Chinese extracts have been translated into English verbatim by the author. The extracts which are not marked "translated verbatim from Chinese" are transcribed without any change, including the language mistakes made by the teachers. The teachers' original words in the videos are shown in italics, Type small 5.

\section{The Discursive Resources in the Construction of an Authoritative Teacher}

\subsection{Subject Matter Expert}

The overall mastery of a subject, the understanding of its mechanism, knowledge about the process of acquisition, technical terms, figures and charts are often employed as an indication of professional knowledge. When commenting on the evaluative function of language, Hunston \& Thompson (2000, p. 24) regard its central function as evaluating the degree of certainty of knowledge. Besides the presentation of professional knowledge and employment of technical tools, teachers may increase their credibility as a professional by linguistic devices such as factual assertions. Since facts represent universally acknowledged truth, they help assert the teacher's judgment regarding the content. At the grammatical level, modality (including modal operators and modal adjuncts) represents the social construction of the knowledge system and the relative discourse status of the participants, and interacts closely with the institutional context (He, 1993). High modality asserts the unquestionability and truthfulness of statements. Higher levels of graduation (Martin et al., 2005) may be used to modify propositions or factual assertions to enhance the status of knowledge. For example, intensifiers (e.g. greatly, truly) and extreme expressions (e.g. completely, absolutely, only, never) add to the force of evaluative power. On the other hand, an assertion is made questionable by including expressions of uncertainty, for example, low modality, low graduation, questions tags, etc. The relative discursive position of teachers influences their use of the evaluative function of language, which in turn helps to construct a high or low form of their authority. When propositions are made as statements without modification, teachers take the ontological status of knowledge as the truth and fact, as being affirmative and verifiable, and thus exhibit a high discourse status (He, 1993). 


\section{Extract 1}

So, very often the reason you cannot find a role model in real life is that you don't care a bit about life. Your life becomes unbearable just because you yourself are not in the least beautiful (in heart). True beauty must be directly related with kindness. Real beauty must be genuine. (Translated verbatim from Chinese)

In addition to affirmative sentences with the high value modality verb (must) and expressions at the highest level of "graduation" (not a bit, not in the least, just because) (Martin et al., 2005), Teacher C uses "you"to make her statement more relevant to the present context-her students. A few minutes prior to that, when lecturing on the concept of "beauty," she connected it to grace, good artistic taste, sincerity and other qualities. She located the source of beauty in the heart. In Extract 1, she goes on to explain why "you" cannot find happiness in life. This direct address of "you", accompanied with high modality and negation, aims to correct wrong attitudes among young students, including those sitting in her classroom. As she uses strong assertion, high force of graduation and extreme expressions in the face of her imaginary opponents (students), and negates students' knowledge and way of thinking, she builds a framework with clear standards of right and wrong, with herself representing the correct pole and the students the wrong one. She firmly sets herself up as judge of such ideology and criticizer of immature mindsets, even though beauty is an aesthetic concept about which different people might have different understandings and for which it is difficult to set a standard.

The authority to set standards and to distinguish levels of hierarchy of knowledge is evident in many of the courses videotaped. Typically, teachers characterize the students as having "trouble," "problem," "difficulty," "they can't," "they lack," or "they forgot." In other words, students are described as deficient and incompetent. Classifying students by the teachers' standards is an excluding practice of "closure," where the students are created as "objects", as "good"or "bad", "normal" or "deviant". The authority of the teacher thus becomes an "instrument of control" (Kress \& Hodge, 1979; Hodge \& Kress, 1993).

\section{Extract 2}

Students are more familiar with the Chinese names. Ok, for example, "Timber of Wolves", they say it is "Team of Wolves". They don't know it is "Timber of Wolves". So I may use this as an introduction and I may ask them. If some students happen to know, they would be very happy. It gives them a sense of achievement if they know. On the other hand, if there is something students don't know, I may lead them in. I may even explain a little bit about it. Timber of Wolves. Well, it is made up of "Timber" and "Wolves". This is one point. Well, another point is that NBA has become a culture, an American sports culture. .... Actually the team names, why one is called the Nets, why the other is called the Heats, why another is called Nix, etc. has something to do with their history or geography or tourism or economy. Yeah, they have something related. For example, our Miami Heats or Phoenix Suns, right? You may find that these two teams, Phoenix or Heats are both located in relatively hot areas, relatively hot, yeah.

This extract is part of a demonstration lesson. Teachers have to explain the rationale of their teaching to a group of judges. Many teachers in the demo lessons would justify their insistence on their preferred approaches to teaching based on their categorization of students who, according to them, come to class with a vague understanding of the course, unclear goals and lack of persistence. However, this contestant teacher presents himself as a guide and an interpreter of the knowledge which he is quite sure that the students would be interested in. He attaches great importance to incorporating students' knowledge because it "gives them a sense of achievement." Low modality verbs (may, would) and question tags to interact with the audience are consistently present throughout his demonstration. Using inclusive pronouns like "our" in "our Miami Heats", and the pronoun "you", he chooses to get closer to the audience.

In the interview that follows, the teacher's chief metaphor for the relationship between himself and the students is "friends". This teacher has been rated as one of the most popular teachers in his school for many years.

\subsection{Manager of Class and Course-Related Activities}

The ability to guide learning processes is an important source of teachers' authoritative identity. Similar to the enforcement of authority in subject knowledge, teachers may heighten their status of authority by a type of discourse which includes high modality, high graduation and plain assertions.

\section{Extract 3}

You are a beginner, so you must NEVER expect to "get to that level". The only thing you need to know is "I have to say something, I have to learn something, I have to do something like just a beginner. This is the first principle."(Translated verbatim from Chinese) 
Teacher G stresses her knowledge of the goal of the course. She firmly negates the students' expectation about reaching a certain level of linguistic competence as a result of taking the course. She justifies her negation with the assertion that they are beginners, and it is impossible for beginners to know whether their expectation is realistic or not. She presents herself as possessing systematic knowledge about different phases of learning, so she knows where the students should be placed academically now. Then she gives advice to students with the sentence "the only thing you need to know is...". This actually becomes an order when it excludes other possible approaches to learning. "This is the first principle" serves as a conclusion. The ability to draw conclusions shows she has a full view of the things she is talking about. It is more powerful because this is the first of a series of conclusions, and the students can expect more of them to come. This clear arrangement of things to be done is a kind of management power. This sentence also highlights the importance of her talk, because "principles" are rules about how things work. Together with high modality verbs (must, need to, have to) and extreme expressions (never, the only), this comment on the way students learn is heavily loaded with non-negotiable assertions, commands, and therefore conveys a high discourse status of the teacher.

\section{Extract 4}

So far have you been somehow impressed by Jack, the one who has been talking. All right? So what aspect in fact touched you or impressed you the most? Let's see. ... Share with us what aspect or what kind of personalities do you think that has [sic] impressed you the most. Some adjectives are fine, or if you prefer, some sentences containing these important adjectives. All right, you may now have some little discussion with your neighbors. And in one minute, I will be having some of you voice your opinion on this.

(Students discussing.....) So it's time for us to voice our opinions. Let's see. So who'd like to be the volunteer, will be the very first one?

In this extract, the teacher exhibits her management authority by several means: assigning specific tasks, demanding the participation of all students, setting a time limit for the tasks, and checking the tasks. Modal verbs are mostly of low value (may, would), collective pronouns "we, us" are used to include both the teacher and students, and "do you think" "if you prefer" involve meaning negotiation. The foregrounded element of authority in this extract is the frequent mention of time: "now, talking time", "now it's the time", "in one minute, I will be having...", "it's time for us", and "the very first one". Time specification is one of the most important strategies teachers employ to manage a lesson. Imperatives are also used as commands. But lacking the lexico-grammatical devices to foreground and strengthen her status, her directions and commands are what we would call a weak form of institutional authority.

In the following extract, the teacher resorts to high regulative discourse when she finds students' performance is far from her expectation. According to Hargreaves (1972), students satisfy the identity of the teacher by supporting it. Without students' support, she finds her authoritative identity threatened.

\section{Extract 5}

I've already said that in Passages $A$ and B, there are four blanks (to be filled), very simple blanks. And we have listened to most of them. At least the first three, we have met before. Check how many of the blanks you have got wrong. The four blanks. Since we've listened again, you should be able to write them down. Let's check the answers. What's the first blank? It's "glove"! We met this word in our last test, but many students are again making mistakes. ... How is this word spelt? I have already talked about it. Some pronounce it as [i:ðer], some pronounce it as [aider], but the spelling is the same. ... Now (Teacher Z sighs), this word, again some students have spelt wrongly! (Translated verbatim from Chinese)

Teacher $\mathrm{Z}$ is rather annoyed that the students are repeating their errors in spite of the fact that she has corrected them a few times. This obviously threatens her authority and competence as a teacher. To avoid assuming responsibility for the students' failure, she tries to put the blame on the students. She gives two reasons why students are to blame: first, the words to be filled in are very simple; second, these words have been encountered in previous lessons. This reference to the degree of difficulty and time frame of occurrence is a mark of institutional authority, as the ability to judge the difficulty of an academic task indicates one's academic competence. Reference to time is frequent in the classroom. However, different from the teachers in Extract4, Teacher $Z$ uses a much stronger version of time framing. She not only uses time reference to remind students that they themselves are responsible for their mistakes, but also to refer to the inter-relatedness of the lessons. She uses lots of sentences like "I have just mentioned that," "in the last quiz" and "we've already learned that". Over half of her sentences in the 45-minute lesson begin in the following way:

Now this word..., The next word..., Now the last ..., Blank No. ..., First paragraph ..., I just mentioned... 
The foregrounding of time is an indication of the strict control the teacher wants to have over the class.However, the markedness of power discourse can actually be an indication of the teacher's worry over her power. When power has to be emphasized, it indicates that there is the threat of losing it. For example, the following are Teacher Z's comments on the students' errors:

"I just don't understand why you can't write this correctly!" "You have done wrong again!" "Haven't they written the word clearly in the passage?" "IS it REALLY so hard to remember?" (Translated verbatim from Chinese)

Distinguishing "I", "you", and "they", the teacher sets up a divide between herself and the students. When she said "I just don't understand" and "Haven't they written the word clearly?" she is apparently not just commenting on the correctness of the students' answers, but is passing judgment on their intelligence. Neither is "IS it REALLY so hard to remember?" to be taken as a genuine question expecting an answer. Rather, it is an appraisal of the students' cognitive ability. When appraisal shifts from students' performance to their character and intelligence, academic evaluation turns into evaluation of "social esteem" and "normality" (Martin et al., 2005), thus expanding the scope and upgrading the level of evaluation, giving more authority to the teacher.

Compared with the fact that students don't work very hard after class, disrupting classroom order poses greater threat to teachers' authority because the former only affects the students individually whereas the latter threatens the local authority of the teacher and the immediate instructional goal. In order to stress the importance of herself, she resorts to calling on students by their names to get their attention. In the interview, she explained that "this class is not very attentive. They talk a lot. Sometimes I would warn them. I would say: "Hey, you guys stop talking!' But the effect usually only lasts several minutes. So after we listen to a question, I would deliberately ask that student to stand up and tell me the answer."

The marked negative comment on students is to be understood as the teacher's refusal to take responsibility for the students' inattention. Throughout her lesson, the discursive resources of a highly conscious manager of course pace and negative appraiser of student performance and behavior are foregrounded in a marked way.

\subsection{Model of Tradition and Values}

Traditions are value-laden and time-laden. The possession of these values may bring prestige to teachers and put them in an undefeatable situation, as students' young age means they can't possibly be bearer of such values and traditions.

\section{Extract 6}

How would you express you admire people? You admire your father. However, we don't always express it explicitly since we are Chinese people.

The teacher demonstrates her understanding of the Chinese culture and the way we express our emotions. The basis of her conclusion ("we don't always do this") is deduced from Chinese tradition, i.e., the kind of people we have always been.

\section{Extract 7}

So, do you think it's a good way to ask a girl to call you? You should ask, what's your telephone number? I will call you later. Is that so? You're not experienced, right? So you said, "What's your telephone number? Whenever it becomes sunny, I will call you." Right? Is that so? Yes. So I think you should learn something.

This is a teacher's comment on two students' role play. The boy student is supposed to ask the girl student out on a first date. The teacher makes her comments when it is finished. Obviously, the teacher is not satisfied with their performance. The strong modal verb "should" indicates the position she is taking. This position is further strengthened by a question to students (do you think it's a good way), and a second "should". This question is expected to get a negative answer, as is demonstrated by her following comment. She thinks the boy student is not asking the right kind of question and she judges the reason to be students' inexperience (You're not experienced). Therefore, her comment is based on her worldly knowledge as an older person. After the evaluation, the teacher goes on to give advice (you should learn something). Foregrounding students' lack of experience, she constructs herself as more experienced and wiser in such matters and thus worthy of trust and respect.

Talking about the de-traditionalisation of the modern society, Chouliaraki and Fairclough cited Giddens that "traditions have to explain themselves" $(1999$, p. 81). Values and traditions may need explanation rather than imposition. Students can choose to respect or renounce, follow or reject the traditions and values inherited from a previous generation. In this sense, a strong form of tradition-value claims would make the teacher's stand an imposition on the students' ideology, rather than as one of choice. 


\subsection{Member of Prestigious Groups}

We expect people to take us as belonging to prestigious groups, whose members enjoy socially admired statuses. The prestigious status of our contacts makes us prestigious because their resources may benefit ourselves as well. In a strong form, we make it explicit that we are intimately related with them. Besides, educational background, wealth, high position, place of residence and travel experiences are all admirable because of the scarcity of such resources, and thus may be exploited for their value.

\section{Extract 8}

I have an acquaintance, an elderly gentleman. He is a musician, a Grade A (highest level) singer of the country. When for the first time in Shanghai, the "cassette", that special edition, appeared, recorded in magnetic tape, these songs were sung by him. (Translated verbatim from Chinese)

Here the teacher refers to an elderly gentleman, one of the best singers in China, as her friend. She details his importance with "Grade A, the first, the special edition" so that the image of a prestigious artist is constructed. Since the teacher has such a contact, it describes her own importance as well. According to Goffman, presenting a higher strata or a prestigious position conveys a "desire for a place close to the sacred centre of the common values of society" (Goffman, 1959, p. 36). As this kind of idealization appeals to common values and the teacher is presented as holding some of it, she is closer to the 'sacred centre,' and has a higher strata or a more prestigious position than just being an ordinary teacher.

Throughout her lecture, the reference she makes to the students and young people of this age is mostly negative: Students are described by her as immature, credulous, superficial, etc. The categorization of "us" (the teacher and her contacts) and "them" (students) constructs her as enjoying a higher social status than the students, thus deserving more authority.

\section{Extract 9}

This is a passage about Hawaii, ok? Hawaii. Hawaii is one of the popular destinations for honeymoons, right? Yeah. I dreamed of going to Hawaii for a honeymoon too, but unfortunately when I got married, he (her husband) was not rich enough to afford that (students laugh). Anyway, we went to the beach, $X$ beach, for several days. You still have a chance, right? (Students laugh)

The teacher in this extract does not possess admirable experiences of going abroad for her honeymoon, which is a sign of wealth. The $\mathrm{X}$ beach where she and her husband actually went was near where they lived. Then she expresses an optimistic outlook of the students' future ("You still have a chance, right?"). A humble attitude of one's own experience shows a weak form of authority imposition and places her and her students on more equal footing.

More symbolic capital means more power of control. That is because "The more symbolic capital one has, the greater value the field/market gives to their capital. In turn, one may benefit more from the field/market. The more formal the occasion and the more concentrated the resources, the smaller the gap there is between theoretical value and real value" (Bourdieu, in $\mathrm{Gu} \& \mathrm{Li}, 2007$ ). In the videos, we also find examples of teachers citing their publications, the academic titles they hold, the research projects they are undertaking, and their academic, economic and social entrepreneurship.

\section{A Weak and Strong Framework of Teachers' Institutional Authority}

We assume that an authoritative identity is the result of a series of conscious or unconscious linguistic choices that teachers exploit to construct the kind of image they desire. An analysis of videotaped classroom discourse results in a weak and strong framework of teachers' discursive construction of authority. The strong form stresses knowledge, order, correctness, unitary proposition, timing, evaluation, etc. The constituent of social background is marked by detailed description or deliberate reference to contacts and experiences to highlight the teachers' superiority and prestige.

A weak form of authority is characterized by low or middle modality verbs, low graduation, and an absence of extreme expressions. Teachers may refer to friends and partnerships, but they are cited to relate with students or to tone down the teachers' importance.

The two forms are on a cline from low to high. The exploitation of some strategies in the weak form tends to lower the degree of strength of the strong form, and vice versa. Different combinations result in distinctive kinds of authoritative images. This framework of a combination of the weak and strong forms of authority overcomes the limitation of structural determinism, as we see the active agency of the teacher in the dynamics of instructional contexts. It also accommodates a more complex and stable system of power. This brings out 
different performances of the teachers' authoritative identity, which, as we will see in the following section, will impact the pedagogic discourse of the teacher and the teacher-student relationship.

\subsection{The Relationship of a Strong and Weak Framework of Authority to Pedagogic Discourse}

A strong form of authority is more consistent with the enduring power characteristics of institutional discourse and more resistant to the dynamics of local interaction. This feature of the strong form not only influences the way teachers present themselves, but also the way instruction is carried out. Within this framework, pedagogic discourse becomes more imposing and compelling. Knowledge is presented as absolute, hierarchical and de-contextualized. Information other than book knowledge does not enter the classroom discourse, and choices and alternatives are excluded. The compelling tone demands compliance. Coercive power (Fairclough, 1989; van Dijk, 2001) is brought to the front.

Teacher $\mathbf{J}$ who consistently presents a strong form of authority makes book knowledge and correct answers the center of her teaching. She makes asserted claims of her propositions. Her explanation is seldom enriched with interesting examples or contextual application. Students' knowledge and topics of interests are not included in her pedagogic discourse. Her class is inflexible and is not interesting. Students often doze off or play with their cell phones. She consistently received low marks in the students' evaluation of her teaching.

When interviewed about her rationale of teaching, she said "Well, the classroom is ... mainly for matters related to the lesson". Asked if she would talk about topics students are interested in, she said, "In class I don't talk about such matters". This rather rigid understanding of what the classroom discourse should include and exclude shows that she limits her identity to "subject-matter expert" and limits pedagogic discourse to being strictly knowledge-relevant. Topics not related to serious book knowledge is not what she thinks should be talked about. Allowing such topics in the classroom would mean that the students' interest and knowledge could also have the status of "knowledge". But this status is something she is unwilling to grant to students. The declarative clause ("Well, the classroom is ... mainly for matters related to the lesson") with an affirmative mood is her definition of the classroom and pedagogic discourse.

The strong form of authority of pedagogic discourse also impacts the way students' errors are treated. When teachers take knowledge as something fixed, as facts and rules, they expect students to accept it without questioning and preserve it in its original form. Students should be able to reproduce and apply it correctly in similar situations. Students' errors mean that they are not learning the knowledge the way the teacher taught them. Or if they tried and still err, it would mean that they are cognitively deficient. This is the reason why Teacher J. often says "Wrong again! Why?" "I just mentioned this word!'”I seems to her that lack of knowledge or incomplete possession of knowledge is equal to being on the lower level of the knowledge hierarchy.

\subsection{The Relationship of a Strong and Weak Framework of Authority to Teacher-Student Power Relationship}

One's identity consciousness includes the definition of the other party's identity status. Wright (1987) thinks roles - the acting out of identity - are complementary. The assumption of one role automatically sets up a complementary one. The authority of teacher as subject matter expert automatically supposes the students to be knowledge-inadequate. For example, a teacher talks about her students in this way:

\section{Extract 10}

She (one of her students) wrote a lot and it teaches me. I thought, students are educators, they can teach their teachers, they can teach their peers. So when the students are motivated, they are activated, their learning is powerful. You don't need to push them or encourage them. They'll just learn! ... In my class, I don 't need to push them, I just say, "Do not work too hard. You need to take a rest." And health is very important. So when they come to the class, especially during the fifth period, I would ask them to bring food to the class. I would ask them to bring drink to the class. And sometimes I would bring something, take something to them to eat because I feel hungry at that time. When I feel hungry I cannot teach.

In this passage, the teacher does not construct herself in the traditional teacher's role. Firstly, her students can be teachers, teaching peers and even their teachers. This puts the teacher in the role of a learner. Secondly, students can be motivated learners, so the teacher can let them take over part of the role as manager. Thirdly, students are young people with basic needs. When they feel hungry, they can't concentrate. The teacher is just like them, and would not be able to continue teaching when she feels hungry. So teacher and students are both ordinary human beings. They are equal. In her talk, there is no subject-matter-expert identity, no manager identity, no insistence on rules and values of her own. When she takes the weak form of authority and learns more about the students, she finds "that every student is different. How can I teach the same way and give them the same thing?" This brought about the radical changes in her pedagogic discourse. 
When asked whether she would chat with students about the topics they are interested in after class, Teacher J, representing the strong form of authority, said:

\section{Extract 11}

I would chat with them for a short while during the break time, for example, what are the hot topics these days, what has happened, etc. I would be informed of such topics myself, but I don't chat with them. For example, there was an earthquake, and I would talk about the earthquake. And then I told them that we should donate money, and things like that. The generation gap exists in the differences of ideology. They may enjoy certain topics, like computer games, but I just don't like them. (Translated verbatim from Chinese)

Teacher J keeps her identity by setting up boundaries: firstly, she roughly knows what topics students are currently interested in, but she is not interested. She classifies herself as different from students. Secondly, the students' topics are not for the classroom. With this, she strictly defines what she does in the classroom and what she does not do, and thus defines the way classroom power-relationship should be. The break-time chat is more of a casual type, but she would direct it to moral values, and she acts as the role model. In the interview, she also said that when students organized outings and invited her, she never went. This insistence on the strong form of authority distanced her from other possible identity choices and makes the authoritative role the sole one that she occupies and presents in education-related contexts.

\section{Discussion}

As can be seen from the above analysis, various factors influence teachers' authoritative identity. The authority of the subject matter expert and class manager constitutes a major part of their authority in the classroom. In the sense that it carries greater weight than the minor constituent parts like background and experiences, a strong form of expert and manager impacts teachers' discourse the greatest. In the above analysis, the strong form of authority brings forth rigid management styles and makes the teachers' pedagogic discourse less compatible with local needs.

However, we propose that the authoritative stance is not entirely determined by the authority resources brought into the classroom, nor is it fixed. Rather, it is actively negotiated through situated talk. The nature of their influence lies ultimately with the choices that teachers make.

There are two features of authoritative identity that make it powerful in the classroom context. Firstly, an institutional identity has the features of being stable, sustainable and repeatable, as it is the product of rather stable and persistent systems of power relations in society. Jaffe (2009) terms it metaidentity. This refers to durable personal stances across longer time frames, the cumulative patterning of one's identity choices that constitute their unique stance, and thus their identity as linguistic individuals, "defined by multiple iterations (and consumption) of discourses of distinction" (Jaffe, 2009, p. 19). When activated, it automatically starts to reproduce itself in order to keep control. This activation of identity structure reconfirms the status of the speaker, and we see the social relationship in the classroom going on as if it had always existed, even though it is the first class meeting of the teacher and students. The stability and predictability of the structure make teachers feel safe and in control.

Secondly, authoritative identity is not only self-confirming and other-confining, it is also evaluative. It evaluates social groups as good or bad, right or wrong, compliant or non-compliant. When teachers find a certain element beneficial for the establishment of their authority, they regard it as more consistent with their self-image. They employ more linguistic resources to highlight its importance. On the other hand, they may refuse to acknowledge an identity which they find irrelevant to their purpose, or which they think would lower the importance of their institutional identity. When their identity becomes more or less fixed, it would go on to stereotype their complementary role - the students. This explains why some teachers are concerned about their inability to exercise their authority, because this failure, or the failure of students to support their displayed authority, is detrimental to the value of their professional identity.

The above analysis shows teachers' authoritative identity in its diverse forms, contributing to different pedagogic discourses and teacher-student relationships. We believe that we are justified in our assumption that teachers' authoritative identity is partially constructed and negotiated through verbal discourse. Even though teachers may be powerfully influenced by institutional identity, we find that there is always this negotiation going on in the classroom. Even the most rigid adherents to teacher authority have been observed to negotiate their power and respond to changes in the social structure of the classroom.

Confinement to institutional authority makes teachers' discourse more institutional. Not only does it impact their pedagogic discourse, but it reproduces the hierarchical social order. However, according to our classroom 
observation, this kind of social order does not provide students with positive social identities to engage in learning, because it denies students educational equity and social justice. In an increasingly democratic society, especially in universities where different ideas are encouraged, this stereotyping of relationship goes against the trend of social development. It is hoped that this framework of analysis will give teachers an increased awareness of their professional identity and of the impact of an authoritative stance on pedagogic discourse.

\section{Conclusion}

The study of the discursive construction of authority can be used as an analytic framework within which to examine the discursive resources that teachers use to explain, justify and make sense of themselves in relation to the students, and of education at large. Through the evaluation of their discursive choices and modes of presentation, the positionings of teachers can be seen to impact the most essential parts of the teaching process. The strong and weak forms of authority can be illustrated through the importance that teachers ascribe to the claim of their desired identities. The strong form, framed through a high degree of certainty and discursive force about the teachers' high status and social position, reveals their insistence on the traditional role. We would like to caution against this discursive stand. In this age of the Internet, one major source of the teacher's authority — subject matter - might be threatened, as "the wide distribution of knowledge in societies erodes distinctions between expert and non-expert actors and organizations and thus the authority of experts and professionals." (Henkel, 2010, p. 7) The traditional differential categorizations of "knowledge", the "teacher" and the "learner", as well as traditional ways of learning are challenged. This challenge obliges teachers to reflect on where their authority comes from, what kind of authoritative identity they wish to take, and what kind of relationship they wish to build with students.

\section{Acknowledgements}

Thanks are due to Sally Ross for providing me with language help.

\section{References}

Antonek, J. L., McCormick, D. E., \& Donato, R. (1997). The student teacher portfolio as autobiography: Developing a professional identity. The Modern Language Journal, 81, 15-27. http://dx.doi.org/10.1111/j.1540-4781.1997.tb01624.x

Barnes, D., Britton, J., \& Torbe, M. (1969). Language, the Learner and the School. Penguin Books.

Beauchamp, C., \& Thomas, L. (2009). Understanding teacher identity: An overview of issues in the literature and implications for teacher education. Cambridge Journal of Education, 39, 175-189. http://dx.doi.org/10.1080/03057640902902252

Beijaard, D. (1995). Teachers' prior experiences and actual perceptions of professional identity. Teachers and Teaching: Theory and Practice, 1(2), 281-294. http://dx.doi.org/10.1080/1354060950010209

Beijaard, D., Verloop, N., \& Vermunt, J. D. (2000). Teachers' perceptions of professional identity: An exploratory study from a personal knowledge perspective. Teaching and Teacher Education, 16, 749-764. http://dx.doi.org/10.1016/S0742-051X(00)00023-8

Beijaard, D., Meijer, P. C., \& Verloop, N. (2004). Reconsidering research on teachers' professional identity. Teaching and Teacher Education, 20, 107-128. http://dx.doi.org/10.1016/j.tate.2003.07.001

Bernstein, B. (1990). Class, Codes and Control Volume IV: The Structuring of Pedagogic Discourse. London: Routledge. http://dx.doi.org/10.4324/9780203011263

Cazden, C. B. (2001). Classroom Discourse: The Language of Teaching and Learning. Portsmouth: Heinemann.

Chouliaraki, L., \& Fairclough, N. (1999). Discourse in Late Modernity: Rethinking Critical Discourse Analysis. Edinburg University Press.

Christie, F. (2002). Classroom Discourse Analysis: A Functional Perspective. London: Continuum.

Coldron, J., \& Smith, R. (1999). Active location in teachers' construction of their professional identities. Curriculum Studies, 31, 711-726. http://dx.doi.org/10.1080/002202799182954

Connelly, F. M., \& Clandinin, D. J. (1999). Shaping a professional identity: Stories of educational practice. New York: Teachers College Press.

De Fina, A., Schiffrin, D., \& Bamberg, M. (Eds.). (2006). Discourse and Identity. Cambridge University Press. http://dx.doi.org/10.1017/CBO9780511584459

Duff, P. A., \& Uchida, Y. (1997). The Negotiation of Teachers' Sociocultural Identities and Practices in 
Postsecondary EFL Classrooms. TESOL Quarterly, 31, 451-486. http://dx.doi.org/10.2307/3587834

Fairclough, N. (1989). Language and power. Addison Wesley Longman Limited.

Gee, J. P. (2001). An Introduction to Discourse Analysis: Theory and Method. London: Routledge.

Gee, J. P. (2005). An Introduction to Discourse Analysis: Theory and Method (2nd ed.). Routledge.

Grad, H., \& Rojo, L. M. (2008). Identities in discourse: An integrative view. In R. Dolón, \& J. Todoli (Eds.), Analyzing identities in Discourse (pp. 3-28). John Benjamins Publishing Co.

Gu, X., \& Li, Y. (2007). Language and Identity Construction: Literature Review. Foreign Language Research, 6, 101-108. http://dx.doi.org/10.3969/j.issn.1000-0100.2007.06.020

Gumperz, J. J., \& Cook-Gumperz, J. (1982). Introduction: Language and the communication of socialidentity. In J. J. Gumperz (Ed.), Language and social identity. Cambridge University Press.

Halliday, M. A. K. (1985). An Introduction to Functional Grammar. London: Edward Arnold.

Hargreaves, D. H. (1972). Interpersonal Relations and Education. London: Routledge and Kegan Paul.

He, A. W. (1993). Exploring modality in institutional interactions: Cases from academic counseling encounters. Text, 13, 503-528. http://dx.doi.org/10.1515/text.1.1993.13.4.503

Henkel, M. (2010). Introduction: Change and Continuity in Academic and Professional Identities. In G. Gordon, \& C. Whitchurch (Eds.), Academic and Professional Identities in Higher Education: The Challenges of a Diversifying Workforce (pp. 3-12). New York: Routledge.

Hodge, R., \& Kress, G. (1993). Language as Ideology (2nd ed.). London: Routledge.

Hunston, S., \& Thompson, G. (2000). Evaluation in Text. Oxford University Press.

Jaffe, A. (2009). Stance, Style and the Linguistic Individual. In A. Jaffe (Ed.), Stance: Sociolinguistic Perspectives (pp. 29-52). New York: Oxford University Press.

Kamila, C. (Ed.). (2011). Identity through a Language Lens. Peter Lang Pub, Inc.

Kress, G., \& Hodge, R. (1979). Language as ideology. London: Routledge \& Kegan Paul.

Manke, M. P. (1997). Classroom Power Relations: Understanding Student-Teacher Interaction. Mahwah, New Jersey: Lawrence Erlbaum Associates.

Martin, J. R., \& White, P. R. R. (2005). The Language of Evaluation: Appraisal in English. New York: Palgrave Mcmillan.

Mawhinney, H., \& Xu, F. (1997). Restructuring the professional identity of foreign-trained teachers in Ontario schools. TESOL Quarterly, 31, 632-639. http://dx.doi.org/10.2307/3587847

McInnis, C. (2010). Traditions of Academic Professionalism and Shifting Academic Identities. In G. Gordon, \& C. Whitchurch (Eds.), Academic and Professional Identities in Higher Education: The Challenges of a Diversifying Workforce (pp. 147-165). New York: Routledge.

Preuss, E., \& Hofsass, T. (1991). Integration in the Federal Republic of Germany: Experiences related to professional identity and strategies of teacher training in Berlin. European Journal of Teacher Education, 14, 131-137. http://dx.doi.org/10.1080/0261976910140205

Rojo, M. L., \& van Dijk, T. A. (1997). There was a problem, and it was solved! Legitimating the Expulsion of "Illegal" Immigrants in Spanish Parliamentary Discourse". Discourse \& Society, 8(4), 523-567. http://dx.doi.org/10.1177/0957926597008004005

Rymes, B. (2009). Classroom Discourse Analysis: A Took for Critical Reflection. Cresskill, NJ: Hampton Press.

Samuel, M., \& Stephens, D. (2000). Critical dialogues with self: Developing teacher identities and roles-A case study of South African student teachers. International Journal of Educational Research, 33, 475-491. http://dx.doi.org/10.1016/S0883-0355(00)00030-6

Seliger, H. W., \& Long, M. H. (Eds.). (1983). Classroom Oriented Research in Second Language Acquisition. Newbury House Publisher, Inc.

Sinclaire, J., \& Coulthard, M. (1992). Towards an Analysis of Discourse: The English Used by Teachers and Pupils. In M. Coulthard (Ed.), Advances in Spoken Discourse Analysis (pp. 1-34). London: Routledge.

Siraj-Blatchford, I. (1993). Educational research and reform: Some implications for the professional identity of early years teachers. British Journal of Educational Studies, 41, 393-408. 
http://dx.doi.org/10.1080/00071005.1993.9973975

Tajfel, H. (1974). Social identity and intergroup behavior. Social Science Information, 13, 65-93. http://dx.doi.org/10.1177/053901847401300204

Van Dijk, T. A. (1995). Discourse semantics and ideology. Discourse and Society, 6, 243-289. http://dx.doi.org/10.1177/0957926595006002006

Van Dijk, T. A. (1996). Discourse, Power and Access. In R. C. Caldas-Coulthard, \& M. Coulthard (Eds.), Texts and Practices: Readings in Critical Discourse Analysis (pp. 84-104). London: Routledge.

Van Dijk, T. A. (2001). Critical Discourse Analysis. In D. Tannen, D. Schiffrin, \& H. Hamilton (Eds.), The Handbook of Discourse Analysis (pp. 352-371). Oxford: Blackwell.

Van Dijk, T. A. (2008). Discourse and Power. Palgrave Macmillan.

Van Leeuwen, T. (1996). The representation of social actors. In R. C. Caldas-Coulthard, \& M. Coulthard (Eds.), Texts and Practices: Readings in Critical Discourse Analysis (pp. 32-70). London: Routledge.

Weiss, G., \& Wodak, R. (Eds.). (2003). Critical Discourse Analysis: Theory and Interdisciplinarity. Palgrave Macmillan.

Wetherell, M. (2010). The Field of Identity Studies. In M. Wetherell, \& C. T. Mohanty (Eds.), The SAGE Handbook of Identity (pp. 3-26). London: SAGE Publications.

Wright, T. (1987). Roles of Teachers and Learners. Oxford University Press.

\section{Copyrights}

Copyright for this article is retained by the author(s), with first publication rights granted to the journal.

This is an open-access article distributed under the terms and conditions of the Creative Commons Attribution license (http://creativecommons.org/licenses/by/3.0/). 